\title{
Miocene siliceous microfossils from the open cast coal mine Gračanica (Bugojno paleolake, Bosnia and Herzegovina) and their significance: a preliminary report
}

\author{
Andrzej Pisera $^{1}$ (D) $\cdot$ Peter A. Siver $^{2}$ - Oleg Mandic ${ }^{3}$
}

Received: 1 June 2018 / Revised: 21 September 2018 / Accepted: 28 February 2019 / Published online: 15 April 2019

(C) The Author(s) 2019

\begin{abstract}
The Langhian (middle Miocene) marls of lacustrine succession cropping out in the open cast coal mine Gračanica (Bugojno basin, central Bosnia and Herzegovina) yielded a rich siliceous microfauna. The most common are sponge spicules (megascleres), less common are diatoms and chrysophyte cysts. Cell wall remains of a green alga Botryococcus sp. were often observed in one sample. The most common spicules are spinose oxeas that strongly resemble the extant species Ochridaspongia rotunda Arndt, 1937 (family Malawispongiidae Manconi and Pronzato, 2002) that is endemic to Lake Ohrid, and we believe that the fossil material belongs to the same genus. Other, much less common spicules, birotules and thick smooth strongyles were attributed to the genus Ephydatia Lamouroux, 1816 (family Spongillidae Gray, 1867) and most probably Potamolepidae Brien, 1967 respectively. All together, they belong to 5-6 different taxa. The diatoms are represented by 11 species, the most common being Staurosirella leptostauron (Ehrenberg) D.M.Williams and Round 1988, Epithemia sp., Ellerbeckia sp. and Encyonema sp. Much less common are Staurosirella pinnata (Ehrenberg) D.M.Williams and Round 1988 and two undetermined species of Fragilaria as well as Eunotia. Eleven chrysophyte cyst morphotypes were uncovered. Alkaline and oligotrophic conditions in the paleolake are suggested by the presence of the representative of the genus Ochridaspongia Arndt, 1937 that thrives in such environments. The most common diatom species further suggest that the water of this paleolake was shallow, high in mineral content, alkaline, with a high $\mathrm{pH}$ and moderately to highly productive. Common occurrence of Botryococcus $\mathrm{sp}$. suggests rather oligotrophic condition, indicating that conditions and nutrient levels were variable. The first fossil occurrence of the sponge genus Ochridaspongia indicates that this genus originated not in the Lake Ohrid, but much earlier during the early middle Miocene in the Dinarides Lake System.
\end{abstract}

Keywords Bugojno paleolake $\cdot$ Spongillida $\cdot$ Sponge spicules $\cdot$ Diatoms $\cdot$ Chrysophyte cysts $\cdot$ Botryococcus $\cdot$ Environmental and evolutionary significance

This article is a contribution to the special issue "The drowning swamp of Gračanica (Bosnia-Herzegovina) - a diversity hotspot from the middle Miocene in the Bugojno Basin"

Andrzej Pisera

apis@twarda.pan.pl

1 Institute of Paleobiology, Polish Academy of Sciences, ul.Twarda 51/55, 00-818 Warsaw, Poland

2 Botany Department, Connecticut College, New London, CT 06320, USA

3 Geological-Palaeontological Department, Natural History Museum, Burgring 7, 1010 Wien, Austria

\section{Introduction}

During field trip to the Miocene Bugojno basin (central Bosnia and Herzegovina-Fig. 1), organised in 2016 by the Regional Committee on Mediterranean Neogene Stratigraphy Interim Colloquium "Lake-Basin-Evolution", 20 samples were collected from a 40-m-thick lacustrine succession of the open cast coal mine Gračanica (Mandic et al. 2016). In the search for siliceous sponge remains (Porifera), different lithologies have been sampled mostly from loose blocks of the mining debris. Two of these samples (encoded GR4 and GR9), originated 
from grey laminated marls, yielded a rich siliceous microfauna consisting of sponge spicules, diatoms and chrysophyte cysts. Here, we present a preliminary report on these findings and discuss their significance for palaeoenvironmental reconstruction.

\section{Geological setting}

The lacustrine deposits of the Bugojno basin (Fig. 1) in the central Bosnia and Herzegovina are settled in one of the larger intra-mountain depression of the Dinarides with a total surface of $125 \mathrm{~km}^{2}$. They build an $\sim 900$-m-thick continental succession, composed of three lacustrine to terrestrial depositional cycles. Lower and middle cycles comprise Miocene, the upper cycle Pliocene deposits (Mandic et al. 2016 and references therein). The studied sediments of the open cast coal mine Gračanica are settled in the southeastern part of the Bugojno basin ( $\left.43^{\circ} 59^{\prime} 44.88^{\prime \prime} \mathrm{N} ; 17^{\circ} 31^{\prime} 17.49^{\prime \prime} \mathrm{E}\right)$. The $\sim 40-\mathrm{m}-$ thick succession shows in its lower part an alternation of lignite and marl, representing proximal to distal swamp facies. Upwards, the succession grades to massive and laminated littoral and profundal lacustrine marl. The section is dated bio-magnetostratigraphically to $\sim 15 \mathrm{Ma}$ (Langhian, middle Miocene; Mandic et al., in prep., this issue). The sample lithology marked by grey laminated marls attributes the studied samples to the upper part of the section (Mandic et al. 2016). For a detailed geological

Fig. 1 Location of the Bugojno paleolake basin, Lake Ohrid and the Gračanica open cast lignite mine (modified after Mandic et al. 2012, 2016, base maps from ArcGIS by ESRI Inc.)

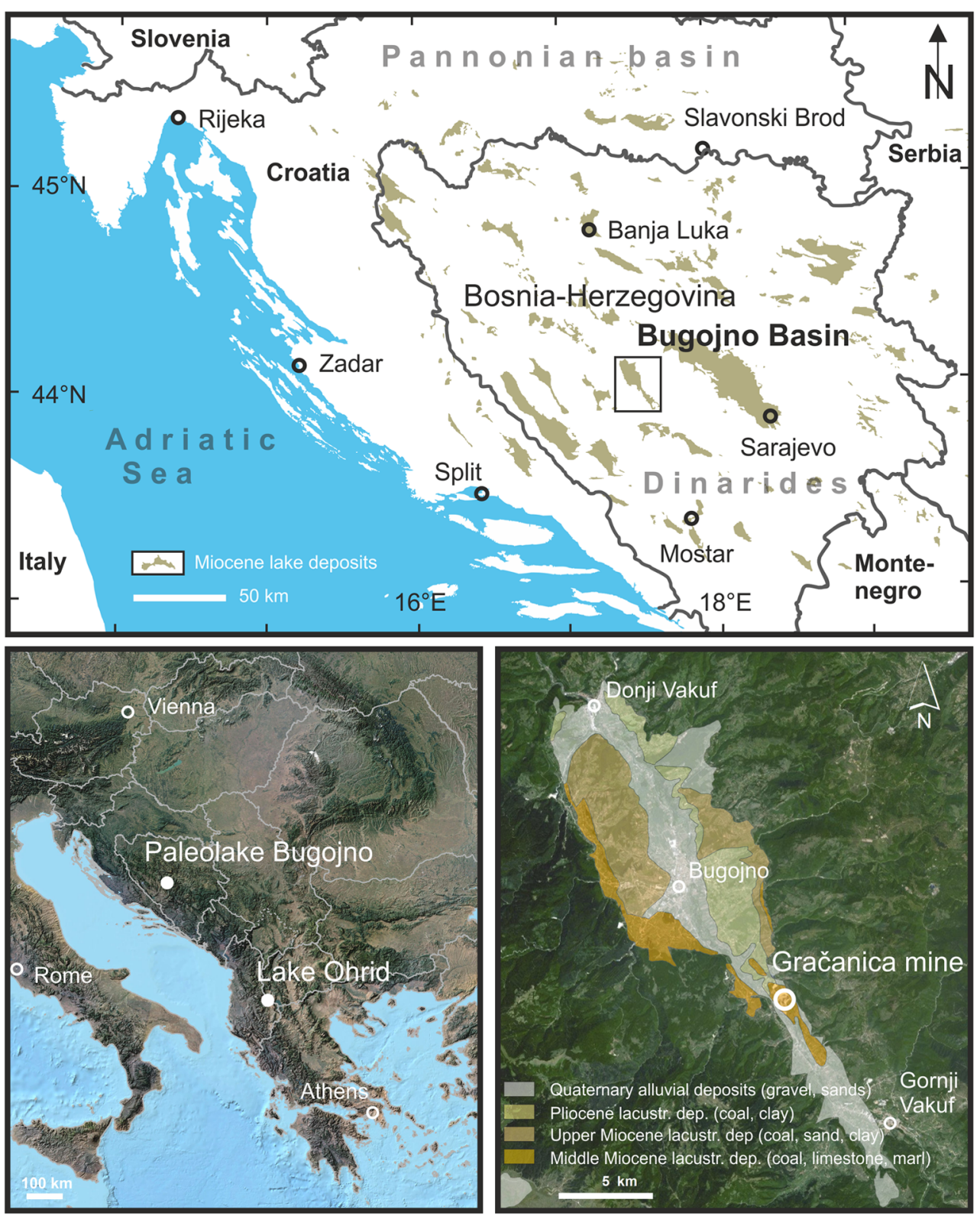


setting and lithofacies description, see Mandic et al. (in prep., this issue).

\section{Material and methods}

Small, about $0.5 \mathrm{~cm}$ large samples of the sediment were treated with hydrogen peroxide during $24 \mathrm{~h}$ in a glass tube. After removal of the reagent, the samples were washed several times in distilled water and finally with pure propanol. Obtained suspensions were used to prepare two standard microscope preparations (slides) from each sample that were later examined in a light microscope (LM). Samples that contained siliceous microfossils were selected and further studied under scanning electron microscopy (SEM). They were dried onto a microscope cover glass, attached with carbon glue to a SEM stub, sputter coated with platinum and examined with a Phillips XL20 SEM at magnifications from $\times 100$ to $\times$ 10,000, at the Institute of Paleobiology, Warsaw.
The studied material is housed in the Institute of Paleobiology, Polish Academy of Sciences, Warszawa under the collection number ZPAL V.64.

\section{Results}

The most common siliceous microfossils in the studied samples are sponge spicules and diatoms. Apart from them, chrysophyte cysts and remains a green alga Botryococcus sp. have been found. The diversity of siliceous microfossils is clearly much higher in sample GR4 compared to sample GR9.

\section{Sponge spicules}

The most common megasclere spicules in both samples GR4 and GR9 (hundreds of specimens in each preparation) are spinose oxeas (Figs. 2a-s and $4 \mathrm{a}-\mathrm{p}$ ) that are from straight (rare) to curved to different degree. Degree of spinosity also

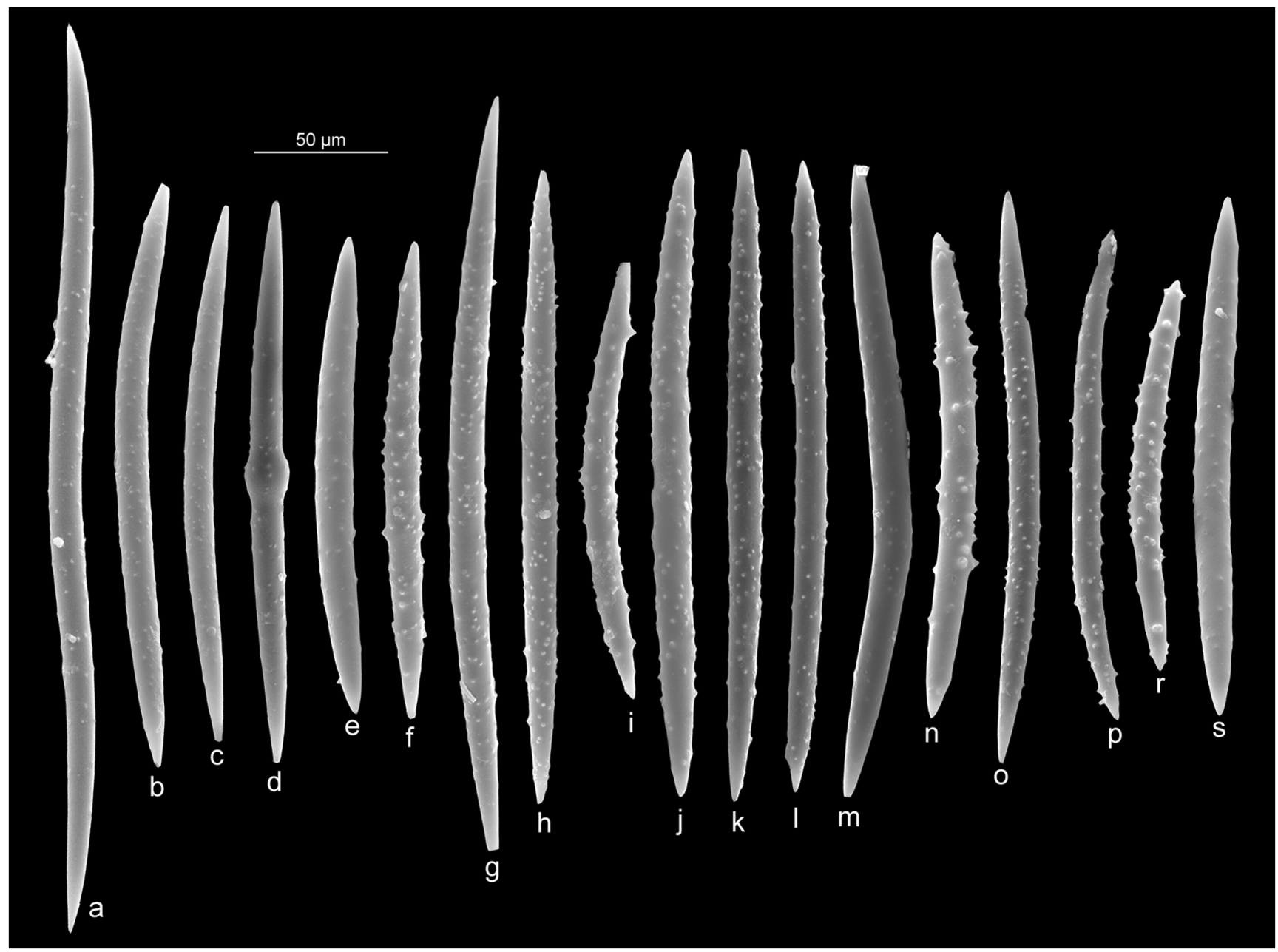

Fig. 2 Megascleres of Ochridaspongia sp. Sample GR4 (ZPAL V.64); note that spicules differ in degree of spinosity and some having central swelling (d) 
differs, and larger spicules have smaller and less numerous spines, while those that are smaller have more and larger triangular spines. Rare centrotylote spicules were also observed (Fig. 2d). The spicules measure 123-282(341) $\mu \mathrm{m}$ in length and are 5-14 $\mu \mathrm{m}$ thick. Morphological comparison with Spongillida (with spiny oxeas as megascleres) presently living on the Balkan Peninsula, e.g. genera Ohridospongilla (Lake Ohrid shallow water), Ochridaspongia (O. rotunda; $O$. interlithonis) and Spongilla (Spongilla stankovici from Lake Ohrid shallow water) led us to conclude that these spicules most closely resemble spicules occurring in the extant species of Ochridaspongia rotunda Arndt (1937) from the Lake Ohrid (Fig. 1) (see Pronzato and Manconi 2001; Albrecht and Wilke 2008) but differ slightly in character of spines, displaying similar shape and size variability (see figures 7 and 8 in Arndt 1937). According to Manconi and Pronzato (2002), the species $O$. rotunda has "Megascleres oxeas (175-367/5-23 $\mu \mathrm{m})$, ranging from slender to stout, from straight to slightly curved, from smooth to spined mainly towards the ends; acerate tips. Spherical swellings occur in some oxeas". These characters fit very well with the studied material except that the fossil spicules are slightly smaller on average than those reported in $O$. rotunda. Due to this differences, and the fact that we have only loose spicules, the specific attribution of fossil material to the extant species from Lake Ohrid is precarious, but we have no doubts that the fossil spicules represent genus Ochridaspongia. Such attribution is further supported by the fact that only megascleres have been found in our material, and no microscleres or gemmuloscleres were observed, as the genus Ochridaspongia is characterised by the presence of megascleres only. The genus is considered as endemic and evolved in the Lake Ohrid or that is a relict of Neogene (Albrecht and Wilke 2008).
Another category of spicules (rather uncommon) that occur in both studied samples (GR4 and GR9) are thick and smooth, usually curved, sometimes contorted strongyles (Figs. 3a-d, $4 \mathrm{r}-\mathrm{s}$ ) that represent gemmuloscleres, such spicules are known in the family Potamolepidae Brien, 1967 (Demospongiae, Spongillida). Similar spicules are known also from other genera of extant freshwater sponges but they are usually accompanied by other types of spicules (Manconi and Pronzato 2002) that were not observed in the studied samples; thus, we consider them as belonging to the Potamolepidae. Very similar spicules attributed to fossil species of Potamophlois canadensis were recently described in an Eocene lake from Northern Canada (Pisera et al. 2013).

The genus Ephydatia Lamouroux, 1816 (Fig. 3h-k) was recognised in the studied Gračanica material (sample GR4), based on the presence (very rare) of gemmular birotules (one aberrant). Large smooth and curved oxeas, co-occurring in the same sample, have also been attributed to this genus. Fossil Ephydatia is known since the Eocene (Pisera et al. 2016; Pronzato et al. 2017). From the Miocene of Europe, the species E. sarmatica Traxler, 1894 was described (Pronzato et al. 2017), but our material is too scarce to allow for specific attribution.

Finally, three spicules of strange morphology (Fig. 3e-g, $\mathrm{e}-\mathrm{f}$, most probably gemmuloscleres) and unknown affinity were found in the sample GR4.

\section{Diatoms}

Eleven diatom species dominated sample GR4, while only one species was recovered in the sample GR9. The most abundant diatom taxa in sample GR4 were Staurosirella leptostauron (Ehrenberg) D.M. Williams and Round 1988

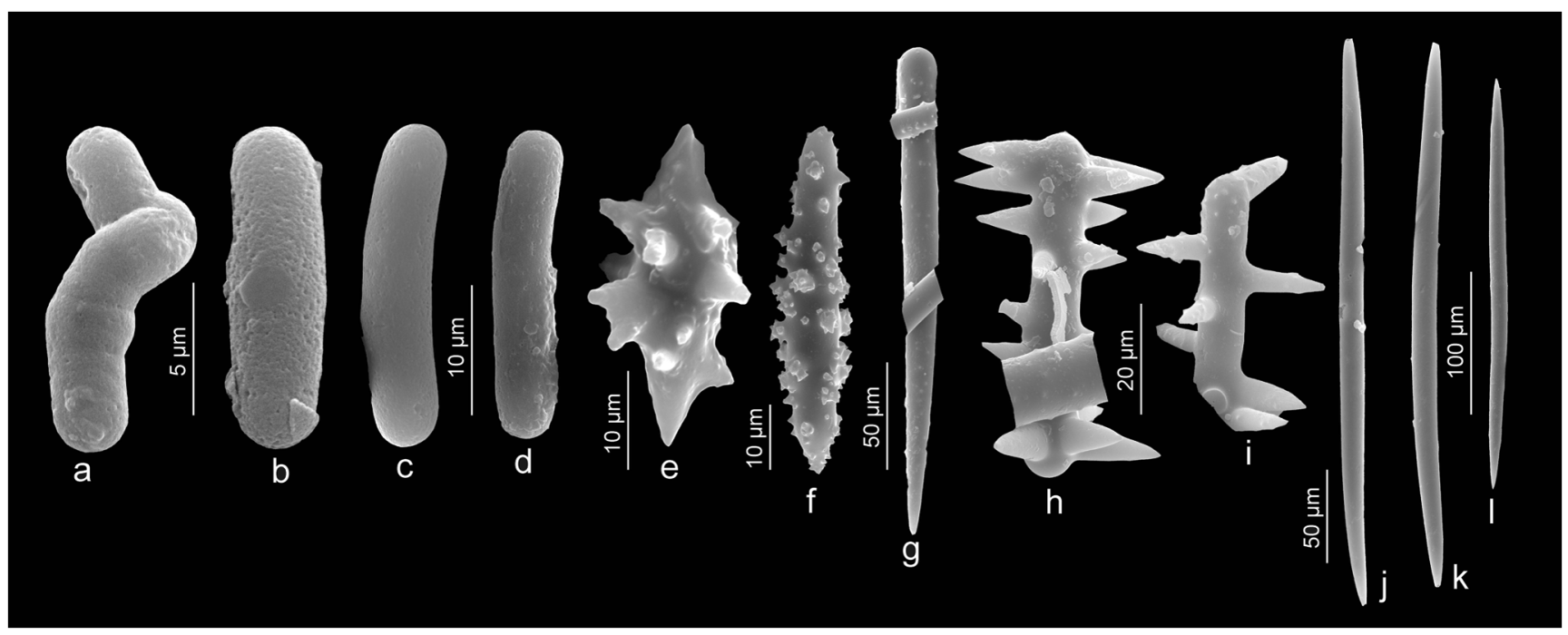

Fig. 3 Sponge spicules, sample GR4 (ZPAL V.64). a-d Spicules (probably gemmuloscleres) of Potamolepidae sponges. e-f spicules (gemmuloscleres) of unknown affinity. $\mathbf{g}$ Undetermined megasclere (style). $\mathbf{h}-\mathbf{l}$ Ephydatia sp. gemmuloscleres (birotules) $\mathbf{h}-\mathbf{i}$ and megasclere oxeas $\mathbf{j}-\mathbf{l}$ 


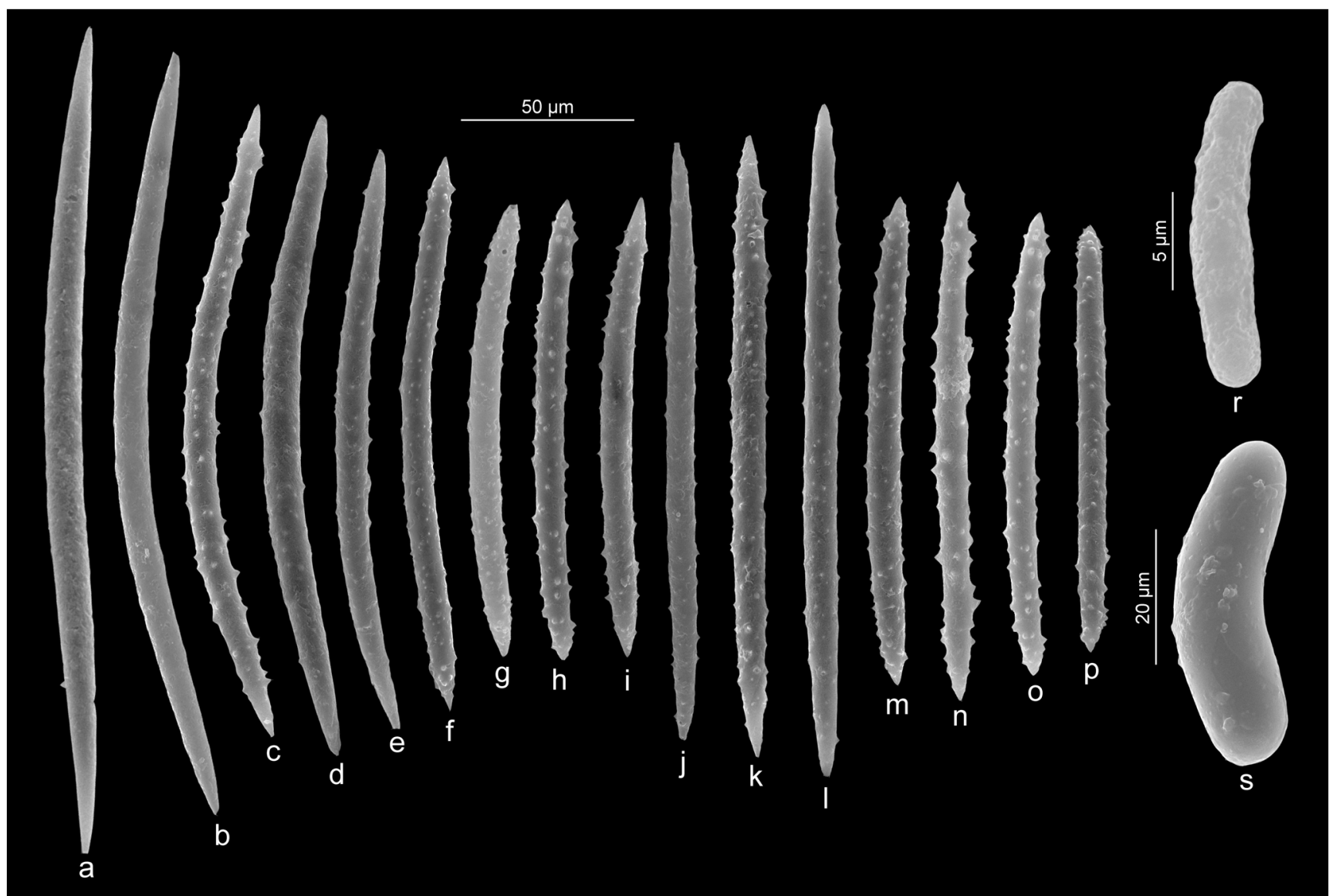

Fig. 4 Sponge spicules a-p megasclere oxeas of Ochridaspongia sp. r-s Spicules (gemmuloscleres) of potamolepid sponges; sample GR9 (ZPAL V.64)

(Fig. 5a-d), Epithemia sp. (Fig. 51-o) and Ellerbeckia sp., possibly E. arenaria (D. Moore ex Ralfs) R.M. Crawford, 1988 (Fig. 5s-v). Valves of S. leptostauron were strongly cruciate with rounded apices, a broad central region, and wide striae consisting of lineolae. Striae were equal to, or slightly smaller than, the diameter of the costae. One or sometimes two spines were situated on each costa near the valve margin and specimens lacked rimoportulae. Characters of the S. leptostauron specimens matched those discussed in detail by Morales (2006) and Morales and Manoylov (2011), and this was the only diatom taxon uncovered in sample GR9. Some characteristics of the Epithemia sp. specimens match those for the genus (Patrick and Reimer 1966; Round et al. 1990). Valves were lunate-shaped, strongly asymmetric about the apical axis, symmetrical about the transapical axis and with rounded apices (Fig. 51-o). Striae were slightly radiate and with internally thickened costae spanning the valve margins. The raphe is eccentrically placed on the valve face with the central area reaching close to the dorsal margin. The girdle was slightly wider along the dorsal margin, and the girdle bands possessed thickened projections that merge internally near the centre of the cell. However, this taxon also has features typically found on its close relative, Rhopalodia O. Müller, 1895, including the structure of the areolae, making identification difficult. Further work is necessary to confirm the relationship of this species within both Epithemia F.T. Kützing, 1844 and Rhopalodia. Characteristics of the Ellerbeckia sp. specimens fit those discussed by Crawford (1988) and Schmid and Crawford (2001). Ellerbeckia sp. (Fig. 5s-v) was the only centric diatom observed in the Gračanica samples. The majority of valves had a marginal ring of parallel thickened ridges on the valve face, or a corresponding ring of depressions on the adjoining valve. The central region of the valve face was hyaline and lacked areolae. The spacing between the ridges within the ring was variable between specimens. The mantle contains numerous rows of small pores characteristic of the genus.

The remaining diatom species uncovered in sample GR4 were less common. Three of the araphid species, including Staurosirella pinnata (Ehrenberg) D.M.Williams and Round 1988 (Fig. 5h) and two species of Fragilaria Lyngbye 1819, belong in the order Fragilariales (Fig. 5j-k). All three of these species possessed marginal spines presumably used to link frustules together into filaments or chains. Multiple specimens of a species of Encyonema F.T. Kützing, 1833 (Fig. 5p-r) and a single specimen belonging to Eunotia Ehrenberg, 1837 (Fig. 5h) were also uncovered in sample GR4. Lastly, a species belonging to the raphe-bearing genus and specimens of 


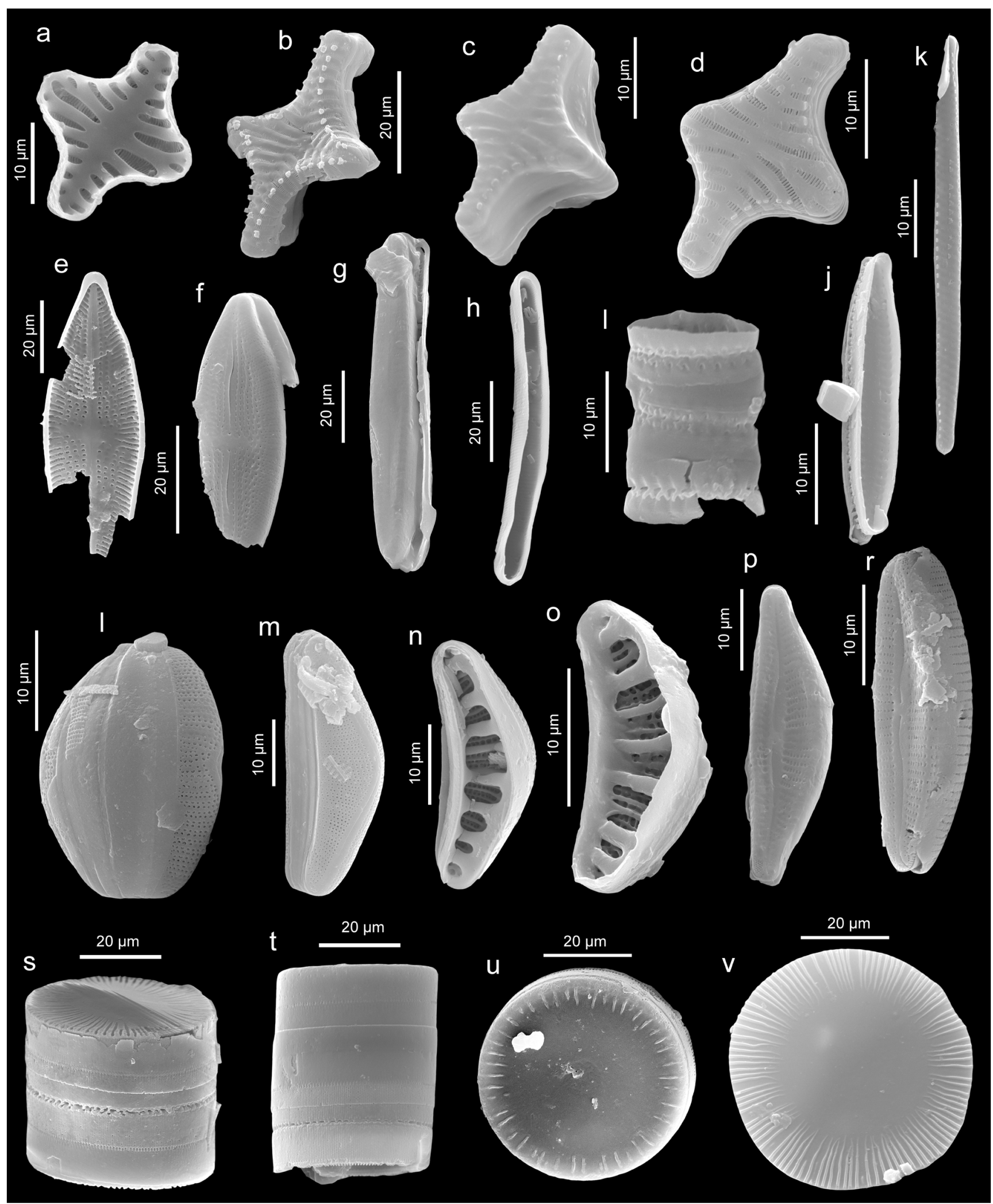

Fig. 5 Diatoms a-d Staurosirella leptostauron. a Sample GR9. b-d Sample GR4. e-f Unknown pennate species. g Undetermined, sample GR4. h Eunotia sp. i Staurosirella pinnata. j Fragilaria sp.1. k Fragilaria sp. 2. 1-o Epithemia sp., sample GR4. p-r Encyonema. s-v Ellerbeckia sp. sample GR4 (ZPAL V.64) 
two unknown pennate species (Fig. 5e-f) were also uncovered in sample GR4.

\section{Chrysophyte cysts}

Cysts in sample GR4, eight different morphotypes, represent a wide diversity with respect to size, wall ornamentation and collar structure (Fig. 6a-h). Cyst morphotype 1 was spherical with a smooth wall, a sunken concave pore and ranged in diameter from 10 to $15 \mu \mathrm{m}$ (Fig. 6c). Cyst morphotype 2 was small with a mean diameter of $6 \mu \mathrm{m}$, and with widely spaced, short, bacculate spines (Fig. 6e). Cyst morphotype 3 was similar to cyst morphotype 1 in size and wall structure, but possessed a distinctive wide $(4.5 \mu \mathrm{m})$, conical collar (Fig. 6d). Cyst morphotype 4 was one of the larger cyst types, with a mean diameter of $22 \mu \mathrm{m}$, and large, widely spaced verrucae (Fig. 6h). Cyst morphotype 5 was similar to types 1 and 3 in size and with a smooth wall, but possessed a wide, short and cylindrical collar (Fig. 6a). The collar structure of cyst morphotype 6 differed from all others in having a shallow, double collar form (Fig. 6b). Cyst morphotype 7 was a common form, large $(22-23 \mu \mathrm{m})$, with closely spaced verrucae and a wide (11-12 $\mu \mathrm{m})$, thick and cylindrical collar (Fig. $6 \mathrm{~g})$. Morphotype 8 was the largest cyst uncovered with a diameter of $35 \mu \mathrm{m}$, spherical and with small, unevenly spaced verrucae (Fig. 6f). This is one of the largest known chrysophyte cysts (Siver 2019).

The three cyst morphotypes uncovered in sample GR9 were all relatively large, with smooth and unornamented walls (Fig. 6i-k) that are different than those recovered from the

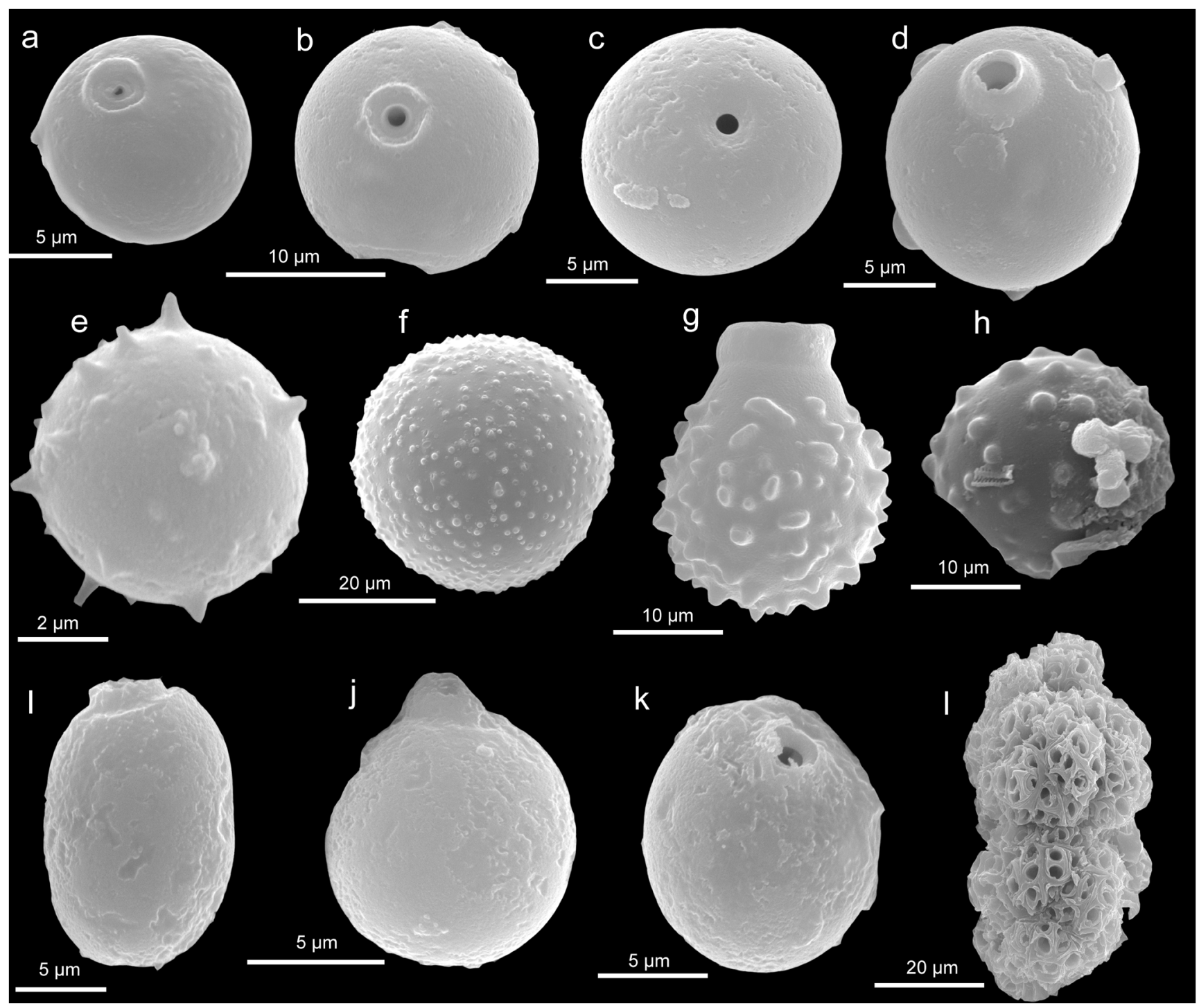

Fig. 6 Chrysophyte cysts a-k. a Morphotype 5. b Morphotype 6. c Morphotype 1. d Morphotype 3. e Morphotype 2. f Morphotype 8. g Morphotype 7. h Morphotype 4. i Morphotype 9. j Morphotype 11. k Morphotype 10. I Botryococcus. a-h Sample GR4. i-l Sample GR9 (ZPAL V.64) 
sample GR4. Cyst morphotype 9, the most common type in sample GR9, was oval, approximately $16 \times 12 \mu \mathrm{m}$ and with a wide collar (Fig. 6i). This morphotype is similar to the ones formed by Mallomonas lychenensis Conrad, 1938 and its allies. Cyst morphotype 10 was spherical with a diameter of $15 \mu \mathrm{m}$, and a shallow collar approximately $2.5 \mu \mathrm{m}$ wide (Fig. 6j). Cyst morphotype 10, a rare form, was slightly oval, $14 \mu \mathrm{m}$ long with what appears to be a thickened rib overhanging the pore (Fig. 6k).

\section{Discussion}

Seven morphotypes of sponge spicules were found in the sample GR4 that were interpreted as representing 6 different sponge taxa, while sample GR9 yielded only two different morphotypes representing two different taxa, but the same occurring also in the sample GR4.

In both samples, one type of spicule belonging to a species of Ochridaspongia dominates the assemblage. This species most closely matches the description of $O$. rotunda, an extant taxon considered endemic to Lake Ohrid. The genus Ochridaspongia is not known from the fossil record. Such taxonomic attribution of the fossil spicules has important consequences for understanding the extant sponge fauna of Lake Ohrid (Albrecht and Wilke 2008): at present, the dominant opinion is that the sponge fauna evolved in the lake between 1.9 and 1.3 Ma ago and remains endemic to the waterbody (Wagner et al. 2017). Given our findings, the case for the genus Ochridaspongia fits the "reservoir hypothesis", because it clearly evolved much earlier in the Miocene (or earlier) in other lakes of the Dinarides Lake Systems (see Mandic et al. 2016), and Ochridaspongia from the Lake Ohrid is the relict of those ancient lake systems, as already speculated by Arndt (1937), Por (1963) and especially Gilbert and Hadzisce (1975, 1977, 1984). Our findings give definitive support for this hypothesis. This does not refute the idea that for other species, the "cradle function" fits.

Our results shed also an interesting light on the question of phylogeny of the genus Ochridaspongia. Meixner et al. (2007) had found that Ochridaspongia may be more closely related to Ephydatia than to other Malawispongiidae (considered as African endemics) suggesting that the family is polyphyletic. Because undoubted Ephydatia occurs in our material from Gračanica, and it is known since the Eocene (Pisera et al. 2016; Pronzato et al. 2017), our find further supports the idea of Meixner et al. (2007) that Malawispongiidae are polyphyletic, and that sponges endemic to isolated freshwater ecosystems originated independently from a few cosmopolitan taxa such as Ephydatia.

Today, waters of the Lake Ohrid, where Ochridaspongia occurs, are slightly alkaline and oligotrophic, and $O$. rotunda inhabits waters 25-70 m deep (Gilbert and Hadzisce 1977).
The presence of potamolepid sponge spicules extends its fossil occurrence to new areas, suggesting that it is present and very restricted distribution (is relict in character, similar to the case with Ochridaspongia.

The sample GR4, with its higher diversity of sponge spicules, indicates the presence of probably 5-6 different sponge species, i.e. Ochridaspongia sp., Ephydatia sp., potamolepid sponge and 2-3 other not identified taxa. The sample GR9 has only two types of sponge spicules attributed here to Ochridaspongia sp. and a species of potamolepid sponge.

Based on the diatom flora uncovered in sample GR4, especially the three most abundant species, the waterbody was shallow, high in mineral content, alkaline and with a high $\mathrm{pH}$. It was also moderately to highly productive. Staurosirella leptostauron is a benthic form commonly reported from alkaline sites with a $\mathrm{pH}$ near 8 (Stoermer et al. 1988; Štefková 2008; Johnson et al. 2009), and known in the fossil record since the Oligocene (Ognjanova-Rumenova and Pipík 2015). This taxon is often found in association with other alkaliphilous species (Štefková 2008), and has been classified as halophobous (Lowe 1974; Ognjanova-Rumenova and Pipík 2015). Taxa belonging to Epithemia are attached forms, largely occurring as epiphytes or epipelic on sediments in shallow environments (Round et al. 1990). As a genus, many Epithemia species are alkalibiontic, often found above pH 8.5 (Whitmore 1989) and common in base-rich waterbodies (Round et al. 1990), including karstic lakes (Jasprica and Hafner 2005). Although a freshwater genus, some species of Epithemia can withstand high dissolved salt concentrations and even brackish water (Pienitz et al. 2006; Staszak-Piekarska and Rzodkiewicz 2015). Ellerbeckia, commonly reported from Miocene localities and often found in association with Actinocyclus and species belonging to order Fragilariales, is primarily a freshwater, benthic genus found in shallow environments (Ramrath et al. 1999; Kociolek and Spaulding 2002). Ellerbeckia can also withstand highly fluctuating water levels, has been found associated with mosses on tufa limestone deposits (Schmid and Crawford 2001) and is often a dominant taxon in karstic lakes (Jasprica and Hafner 2005). In summary, characteristics of the most abundant diatoms found in sample GR4 indicate a shallow water environment that was high in base minerals, highly alkaline and with a high $\mathrm{pH}$.

Other members of the order Fragilariales uncovered in sample GR4, including Staurosirella pinnata and species belonging to Fragilaria, also represent attached forms commonly found in shallow environments at higher $\mathrm{pH}$ values (Jasprica and Hafner 2005; Siver et al. 2005; Pienitz et al. 2006). The single specimen of Eunotia uncovered in sample GR4 does not necessarily match conditions inferred from other diatom taxa. Although some Eunotia species can be found 
in alkaline waters, the genus as a whole encompasses numerous species largely restricted to acidic conditions low in dissolved salts (Siver and Hamilton 2011).

Although the chrysophyte cysts cannot be linked to specific species, the collection of morphotypes uncovered in sample GR4 indicates a relatively high diversity, especially for such an alkaline site. Although there are certainly chrysophytes that grow in alkaline habitats, the majority favour less alkaline, more acidic habitats (Duff et al. 1995; Siver 2015), probably related to their lack of carbon-concentrating mechanisms (Wolfe and Siver 2013).

Compared to sample GR4, the diversity of microfossil remains in sample GR9 was very low. As noted above, the single diatom taxon uncovered in sample GR9, S. leptostauron, likely indicates that this habitat was also shallow and highly alkaline.

The few chrysophyte cysts are also indicative of low diversity, as are sponge spicules. In contrast, sample GR9 was dominated with a species belonging to the green alga Botryococcus sp. The fossils of this organism were well preserved and indicate that it thrived. The genus Botryococcus is known in the fossil record since the Precambrian and has remained virtually unchanged throughout the Phanerozoic (Guy-Ohlson 1992). This planktonic alga, known from tropical to subarctic regions, has been characterised as an indicator of oligotrophic conditions that competes best in shallow and calm conditions, often in areas of low rainfall (Guy-Ohlson 1992; Smittenberg et al. 2005). The capability of Botryococcus to survive long time periods resides in its ability to store excess carbohydrate, a resistance cell wall, and asexual modes of reproduction. These characters may indicate that sample GR9 had low diversity of other microorganisms due to low nutrient levels.

\section{Conclusions}

Grey marls of the lower lake cycle of the middle Miocene Bugojno paleolake (Bosnia-Herzegovina) cropping out in the open cast coal mine Gračanica revealed a diversified assemblage of siliceous microfossils, i.e. 5-6 sponge species, 11 diatom species, 11 morphotypes of chrysophyte cysts, as well as remains of Botryococcus sp. Taxonomic composition of the diatom flora suggests shallow water alkaline environment, which is supported by the presence of Ochridaspongia, found today in alkaline and oligotrophic waters. The two samples examined differ strongly in diversity, possibly associated with different nutrient levels, with more oligotrophic conditions being indicated by the very common occurrence of Botryococcus. This is the first fossil occurrence of the sponge genus Ochridaspongia, indicating that this genus did not originate in Lake Ohrid, and is much older than previously thought dating to at least the middle Miocene.
Acknowledgements We are deeply grateful to our reviewers, Dorte Janussen and Renata Manconi, for their criticism and valuable comments that allowed improvement of the original manuscript.

\section{Compliance with ethical standards}

Conflict of interest The authors declare that they have no conflict of interest.

Open Access This article is distributed under the terms of the Creative Commons Attribution 4.0 International License (http:// creativecommons.org/licenses/by/4.0/), which permits unrestricted use, distribution, and reproduction in any medium, provided you give appropriate credit to the original author(s) and the source, provide a link to the Creative Commons license, and indicate if changes were made.

\section{References}

Albrecht, C., \& Wilke, T. (2008). Ancient Lake Ohrid: biodiversity and evolution. Hydrobiologia, 615, 103-140.

Arndt, W. (1937). Ochridaspongia rotunda n. g., n. sp., ein neuer Süßwasserschwamm aus dem Ochridasee. Archiv für Hydrobiologie, 31, 636-677.

Brien, P. (1970). Les Potamolépides africaines. Polyphyletisme des Eponges d'eau douce. Archives de Zoologie Expérimentale et Générale, 110, 527-561.

Conrad, W. (1938). Notes protistologiques 1.Mallomonas lychenensis, $\mathrm{n}$. sp. Bulletin du Musée Royal d'Histoire Naturelle de Belgique, 14, 1 -

Crawford, R. M. (1988). A reconsideration of Melosira arenaria and M. teres resulting in a proposed new genus Ellerbeckia. In F. E. Round (Ed.) Algae and the Aquatic Environment (pp. 413-433). Bristol: Biopress.

Duff, K. E., Zeeb, B. A., \& Smol, J. P. (1995). Atlas of chrysophycean cysts. Dordrecht: Kluwer Academic Publishers 189pp.

Ehrenberg, C. G. (1837). Über ein aus fossilen Infusorien bestehendes, 1832 zu Brod verbacknes Bergmehl von den Grenzen Lapplands in Schweden. Bericht über die zur Bekanntmachung geeigneten Verhandlungen der Königl. Preuß. Akademie der Wissenschaften zu Berlin, 1837, 43-45.

Gilbert, J. J., \& Hadzisce, S. (1975). Sexual reproduction in the freshwater sponge, Ochridospongia rotunda. Verhandlungen der Internationalen Vereinigung Limnologie, 19, 2785-2792.

Gilbert, J. J., \& Hadzisce, S. (1977). Life cycle of the freshwater sponge Ochridaspongia rotunda Andt. Archiv für Hydrobiologie, 79, 285318.

Gilbert, J. J., \& Hadzisce, S. (1984). Taxonomic notes on the shallowwater endemic sponges of Lake Ohrid, Yugoslavia, with a description of two new species and a redescription of Spongilla stankovici. Archiv für Hydrobiologie, 99, 331-339.

Gray, J. E. (1867). Notes on the arrangement of sponges, with the descriptions of some new genera. Proceedings of the Zoological Society London, 1867, 492-558.

Guy-Ohlson, D. (1992). Botryococcus as an aid in the interpretation of palaeoenvironment and depositional process. Journal of Palaeobotany and Palynology, 71, 1-15.

Jasprica, N., \& Hafner, D. (2005). Taxonomic composition and seasonality of diatoms in three Dinaric karstic lakes in Croatia. Limnologica, 35, 304-319.

Johnson, T., Hermann, K., Spaulding, S., Beyea, B., Theel, C., Sada, R., Bollman, W., Bowman, J., Larsen, A., Vining, K., Ostermiller, J., Petersen, D., Hargett, E., \& Zumberge, J. (2009). An ecological 
assessment of USEPA Region 8 streams and rivers. U.S. Environmental Protection Agency Region 8 Report, 178 pp.

Kociolek, J. P., \& Spaulding, S. A. (2002). Morphological variation, species concepts, and classification of an unusual fossil centric diatom (Bacillariophyceae) from western North America. Journal of Phycology, 38, 821-833.

Kützing, F.T. (1834 '1833'). Synopsis diatomearum oder Versuch einer systematischen Zusammenstellung der Diatomeen, Linnaea. 8, $529-620$.

Kützing, F. T. (1844). Die Kieselschaligen Bacillarien oder Diatomeen. Nordhausen: zu finden bei W. Köhne 152 pp.

Lamouroux, J. V. F. (1816). Histoire des polypiers coralligènes flexibles, vulgairement nommés zoophytes. Caen 1816. (322-352).

Lowe, R. L. (1974). Environmental requirements and pollution tolerance of freshwater diatoms (pp. 334). Cincinnati: U.S. Environmental Protection Agency, EPA 670-/4-74-05.

Lyngbye, H.C. (1819). Tentamen hydrophytologiae danicae continens omnia hydrophyta cryptogama Daniae, Holsatiae, Faeroae, Islandiae, Groenlandiae hucusque cognita, systematice disposita, descripta et iconibus illustrata, adjectis simul speciebus norvegicis. Hafniae [Copenhagen]: typis Schultzianis, in commissis Librariae Gyldendaliae. 248 pp.

Manconi, R., \& Pronzato, R. (2002). Spongillina n. suborder, Lubomirskidae, Malawispongiidae n. fam., Metaniidae, Metschnikowiidae, Paleospongillidae, Potamolepiidae, Spongillidae. In H. J. N. Hooper \& R. W. M. Van Soest (Eds.), Systema Porifera: A guide to the classification of sponges, Vol. 1 (pp. 921-1019). New York: Kluwer Academic/Plenum Publishers.

Mandic, O., Vranjkovic, A., Pavelic, D., Hrvatovic, H., \& De Leeuw, A. (2012). Miocene intra-montane lacustrine basins of Outer Dinarides (Croatia and Bosnia and Herzegovina). In I. Vlahovic, O. Mandic, E. Mrinjek, S. Bergant, V. Cosovic, A. De Leeuw, P. Enos, H. Hrvatovic, D. Maticec, G. Miksa, W. Nemec, D. Pavelic, V. Pencinger, I. Velic \& A. Vranjkovic (Eds.), Marine to continental depositional systems of Outer Dinarides foreland and intramontane basins (Eocene-Miocene, Croatia and Bosnia and Herzegovina). Field Trip Guide, 29th IAS Meeting of Sedimentology Schladming/Austria. Journal of Alpine Geology, $54,456-470$

Mandic, O., Gohlicg, U. B., Krijgsman, W., de Leeuw, A., \& Hrvatovic, H. (2016). Lake Bugojno-three lacustrine cycles. In O. Mandic, D. Pavelić, M. Kovačić, K. Sant, N. Andrić, \& H. Hrvatović (Eds), Field trip guide-book. Lake - Basin - Evolution, RCMNS Interim Colloquium 2016 \& Croatian Geological Society Limnogeology Workshop, 19-24 May 2016, Zagreb, Croatia (pp. 80). Zagreb: Hrvatsko geološko društvo / Croatian Geological Society.

Meixner, M., Luter, C., Eckert, C., Itskovich, V., Janussen, D., von Rintelen, T., Bohne, A. V., Meixner, J. M., \& Hess, W. R. (2007). Phylogenetic analysis of freshwater sponges provide evidence for endemisms and radiation in ancient lakes. Molecular Phylogentics and Evolution, 45, 875-886.

Morales, E. A. (2006). Twelfth NAWQA workshop on harmonization of algal taxonomy. The Academy of Natural Sciences of Philadelphia Report No. 06-03. 193 pp.

Morales, E. A., \& Manoylov, K. M. (2011). Morphological studies on selected taxa in the genus Staurosirella Williams et Round (Bacillariophyceae) from rivers in North America. Diatom Research, 21, 343-364.

Müller, O. (1895). Rhopalodia ein neues Genus der Bacillariaceen. Botanische Jahrbücher für Systematik, Pflanzengeschichte und Pflanzengeographie, 22, 54-71.

Ognjanova-Rumenova, N., \& Pipík, R. (2015). Stratigraphic and taxonomic significance of siliceous microfossils collected from the Turiec Basin, Western Carpathians (Slovakia). Acta Botanica Croatica, 74, 345-361.
Patrick, R., \& Reimer, C.W. (1966). The diatoms of the United States. Monographs of the Academy of Natural Sciences of Philadelphia, vol. 1: Fragilariaceae, Eunotiaceae, Achnanthaceae, Naviculaceae, 688 pp.

Pienitz, R., Roberge, K., \& Vincent, W. F. (2006). Three hundred years of human-induced change in an urban lake: paleolimnological analysis of Lac Saint-Augustin, Quebec City, Canada. Canadian Journal of Botany, 84, 303-320.

Pisera, A., Siver, P., \& Wolfe, A. (2013). A first account of freshwater potamolepid sponges (Demospongiae, Spongillina, Potamolepidae) from the middle Eocene: biogeographic and paleoclimatic implications. Journal of Paleontology, 87, 373-378.

Pisera, A., Siver, P., \& Wolfe, A. (2016). The sponge genus Ephydatia from the high-latitude middle Eocene: environmental and evolutionary significance. Paläontologische Zeitschrift, 90, 673-680.

Por, F. D. (1963). The relict aquatic fauna of the Jordan Valley. Israel Journal of Zoology, 12, 47-58.

Pronzato, R., \& Manconi, R. (2001). Atlas of European freshwater sponges. Annali del Museo Civico di Storia Naturale di Ferrara, 4, 3-64.

Pronzato, R., Pisera, A., \& Manconi, R. (2017). Fossil freshwater sponges: taxonomy, geographic distribution, and critical review. Acta Palaeontologica Polonica, 62, 467-495.

Ramrath, A., Nowaczyk, N. R., \& Negendank, J. F. W. (1999). Sedimentological evidence for environmental changes since 34, 000 years BP from Lago di Mezzano, central Italy. Journal of Paleolimnology, 21, 423-435.

Round, F. E., Crawford, R. M., \& Mann, D. G. (1990). The diatoms. Biology and morphology of the genera (747 pp). Cambridge: Cambridge University Press.

Schmid, A.-M. M., \& Crawford, R. M. (2001). Ellerbeckia arenaria (Bacillariophyceae): formation of auxospores and initial cells. European Journal of Phycology, 36, 307-320.

Siver, P. A. (2015). The Synurophyceae. In J. D. Wehr, R. G. Sheath, \& J. P. Kociolek (Eds.), Freshwater algae of North America: ecology and classification (2nd ed., pp. 605-650). San Diego: Academic Press.

Siver, P. A. (2019). Potential use of chrysophyte cyst morphometrics as a tool for reconstructing ancient lake environments. In: Proceedings of the Ninth International Chyrsophyte Symposium. Nova Hedwigia. Beiheft, 148. https://doi.org/10.1127/nova-suppl/2019/115.

Siver, P. A., \& Hamilton, P. B. (2011). Diatoms of North America: the freshwater Flora of the Atlantic Coastal Plain. Iconographia Diatomologica, 22, 1-920.

Siver, P. A., Hamilton, P. B., Stachura-Suchoples, K., \& Kociolek, J. P. (2005). Diatoms of North America: the freshwater Flora of Cape Cod. Iconographia Diatomologica, 14, 1-463.

Smittenberg, R. H., Baas, M., Schouten, S., \& Sinninghe Damste, J. S. (2005). The demise of the alga Botryococcus braunii from a Norwegian fjord was due to early eutrophication. The Holocene, $15,133-140$.

Staszak-Piekarska, A., \& Rzodkiewicz, M. (2015). Reconstruction of palaeoecological changes in Lake Łebsko on the basis diatom analysis (the southern Baltic coast, Poland). Landform Analysis, 29, 81-90.

Štefková, E. (2008). Diatom species composition in the sediment core of Plešné Lake (Bohemian Forest, Czech Republic). Silva Gabreta, 14, 73-84.

Stoermer, E. F., Kociolek, J. P., Shoshani, J., \& Frisch, C. (1988). Diatoms from the Sheiton Mastodon Site. Journal of Paleolimnology, 1, 193-199.

Traxler, L. (1894). Ephydatia fossilis, eine neu Art der fossilen Spongilliden. Földatni Közlöny, 24, 234-237.

Wagner, B., Wilke, T., Francke, A., Albrecht, C., Baumgarten, H., Bertini, A., Combourieu-Nebout, N., Cvetkoska, A., D'Addabbo, M., Donders, T. H., Föller, K., Giaccio, B., Grazhdani, A., Hauffe, T., Holtvoeth, J., Joannin, S., Jovanovska, E., Just, J., Kouli, K., 
Koutsodendris, A., Krastel, S., Lacey, J. H., Leicher, N., Leng, M. J., Levkov, Z., Lindhorst, K., Masi, A., Mercuri, A. M., Nomade, S., Nowaczyk, N., Panagiotopoulos, K., Peyron, O., Reed, J. M., Regattieri, E., Sadori, L., Sagnotti, L., Stelbrink, B., Sulpizio, R., Tofilovska, S., Torri, P., Vogel, H., Wagner, T., Wagner-Cremer, F., Wolff, G. A., Wonik, T., Zanchetta, G., \& Zhang, X. S. (2017). The environmental and evolutionary history of Lake Ohrid (FYROM/ Albania): interim results from the SCOPSCO deep drilling project. Biogeosciences, 14, 2033-2054.

Whitmore, T. J. (1989). Florida diatom assemblages as indicators of trophic state and pH. Limnology and Oceanography, 34, 882-895.
Williams, D. M., \& Round, F. E. (1988). Revision of the genus Fragilaria. Diatom Res, 2, 267-288.

Wolfe, A. P., \& Siver, P. A. (2013). A hypothesis linking chrysophyte microfossils to lake carbon dynamics on ecological and evolutionary time scales. Global and Planetary Change, 111, 189-198.

Publisher's note Springer Nature remains neutral with regard to jurisdictional claims in published maps and institutional affiliations. 